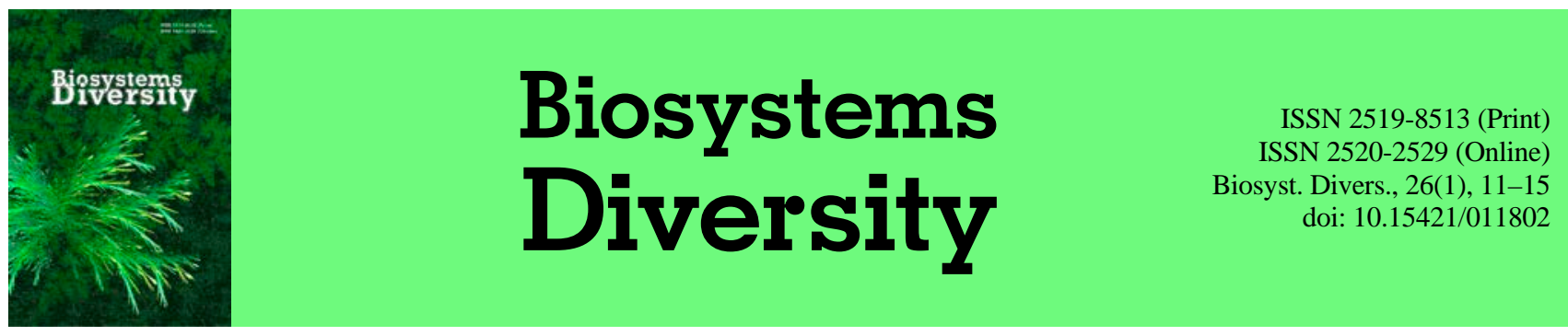

\title{
Prediction of sweet corn yield depending on cultivation technology parameters by using linear regression and artificial neural network methods
}

\author{
P. V. Lykhovyd \\ Institute of Irrigated Agriculture, Kherson, Ukraine
}

Article info

Received 29.01.2018

Received in revised form 14.02.2018

Accepted 16.02.2018

Institute of Irrigated Agriculture, Kherson, Urban-type settlement Naddniprianske,

73483, Ukraine.

Tel.: +38-066-062-98-97. E-mail:

pavel.likhovid@gmail.com

\begin{abstract}
Lykhovyd, P. V. (2018). Prediction of sweet corn yield depending on cultivation technology parameters by using linear regression and artificial neural network methods. Biosystems Diversity, 26(1), 11-15. doi: 10.15421/011802
\end{abstract}

Artificial neural networks and linear regression are widely used in particularly all branches of science for modeling and prediction. Linear regression is an old data processing tool, and artificial neural networks are a comparatively new one. The goal of the study was to determine whether artificial neural networks are more accurate than linear regression in sweet corn yield prediction. In the study we used a dataset obtained from field experiments on the technological improvement of sweet corn cultivation. The field experiments were conducted during the period from 2014 to 2016 on dark-chestnut soil under drip irrigated conditions in the Steppe Zone of Ukraine. We studied the impact of the moldboard plowing depths, mineral fertilizer application rates and plant densities on the crop yield. A significant impact of all the studied factors on the sweet corn productivity was proved by using the analysis of variance. The highest yield of sweet corn ears without husks $\left(10.93 \mathrm{t} \mathrm{ha}^{-1}\right)$ was under the moldboard plowing at the depth of 20-22 cm, mineral fertilizers application rate of $\mathrm{N}_{120} \mathrm{P}_{120}$, plant density of 65,000 plants ha ${ }^{-1}$. Data processing by using the linear regression and artificial neural network methods showed that the latter is a great deal better than linear regression in sweet corn yield prediction. Higher accuracy of the artificial neural network prediction was proved by the higher value of the coefficient of determination $\left(\mathrm{R}^{2}\right)-0.978$, in comparison to 0.897 for the linear regression prediction model. We conclude that artificial neural networks are a much better data processing tool, especially, in the life sciences and for prediction of the non-linear natural processes and phenomena. The main disadvantage of the neural network models is their "black box" nature. However, linear regression will not lose its popularity among scientists in the nearest future. Linear regression is a much simpler data analysis tool, it is easier to perform the prediction, but it still provides a sufficiently high level of accuracy.

Keywords: mathematical modeling; data processing; plowing depth; mineral fertilizers; plants density; drip irrigation

\section{Introduction}

We cannot imagine modern science without using mathematical methods. They are used for statistical data analysis, modeling and forecasting different artificial and natural processes and phenomena. The most popular methods among scientists are regression analysis and artificial neural networks. Regression models have been well-known since the second half of the XX century and have been used for a long time, but they still provide a high enough level of accuracy and are widely used for data processing with different purposes. Artificial neural networks are a comparatively new data processing method with a quite different algorithm. Neural networks are supposed to be better for prediction and modeling of natural phenomena, because of their non-linear nature (Cross et al., 1995). Neural networks are in a great demand in agriculture (Kaul et al., 2005; Uno et al., 2005; Ji et al., 2007; Alvarez, 2009; Panda et al., 2010). There are some studies devoted to compareson of regression and artificial neural networks prediction models by the criteria of their accuracy, facilities, usage easiness, intelligibility, etc. (Refenes et al., 1994; Lek et al., 1996; Tu, 1996; Comrie, 1997; Zhang et al., 1998; Lek \& Guegan, 1999; Lee et al., 2017). The goal of our study was to compare linear regression and artificial neural network accuracy in sweet corn yield prediction.

\section{Materials and methods}

Field experiments. For comparison of the prediction methods, we used the average three-year experimental sweet corn (Zea mays ssp. saccharata Sturt.) ear yield data. The field experiments devoted to the improvement of sweet corn cultivation technology were conducted by using the split plot design method in four replications in the period from 2014 to 2016 on the irrigated lands of the Agricultural Cooperative Farm "Radianska Zemlia" (Bilozerskiy district of the Kherson region, Ukraine; latitude $46^{\circ} 43^{\prime} 42^{\prime \prime} \mathrm{N}$, longitude $32^{\circ} 17^{\prime} 38^{\prime \prime}$ E, altitude $42 \mathrm{~m}$ ).

The field experiments were held on dark-chestnut solonets soil. The humus content in the $0-50 \mathrm{~cm}$ soil layer was $2.5 \%$. The bulk density of the $0-100 \mathrm{~cm}$ soil layer was $1.35 \mathrm{t} \mathrm{m}^{-3}$. The lightly-hydrolized nitrogen content (determined by the methodology of Kornfield) was $35 \mathrm{mg} \mathrm{kg}^{-1}$, the mobile phosphorus content (determined by the methodology of Machygin) was $32 \mathrm{mg} \mathrm{kg}^{-1}$, the exchangeable potassium content (determined by the methodology of Machygin) was $430 \mathrm{mg} \mathrm{kg}^{-1}$ in the arable soil layer.

The climate conditions of the vegetation period were unstable and contrasting (Table 1). The driest and hottest year was 2014, the most unstable with changeable weather was 2015, and the most moderate weather conditions were observed in 2016. All the meteorological observations were held at the Kherson Regional Hydrometeorological Station.

We studied the following factors: Factor A - tillage (moldboard plowing at the depth of 20-22 and 28-30 cm); Factor B - mineral fertilizers application rates (no fertilizers applied; $\mathrm{N}_{60} \mathrm{P}_{60} ; \mathrm{N}_{120} \mathrm{P}_{120}$ of active substance applied); Factor C - plant density (35,000, 50,000, $65,000,80,000$ plants $h^{-1}$ ). Sweet corn yields (in the ears without husks) were determined by the hand-harvesting of fruits from the entire plot area with further weighing on electronic analytical scales. The sweet corn cultivar used in the field experiments was Brusnytsia (standard sweet - su), originated by the Skvyrska Research Station of the Institute of Vegetable and Melon Growing, National Academy of Agrarian Sciences of Ukraine. The sweet corn cultivation technology in 
the field experiments was standard for crop growing under the irrigated conditions in the South of Ukraine. Mineral fertilizers (ammonium nitrate and superphosphate) were applied in accordance to the experimenttal design in the pre-plowing period by the means of seed drill. The previous crop was winter wheat. Stubbling at the depth of 10-12 cm followed by moldboard plowing was conducted after the previous crop harvesting. Soil cultivation at the depth of 8-10 and then at the depth of $5-6 \mathrm{~cm}$ was conducted in the spring. The sweet corn was sown at the depth of $5-6 \mathrm{~cm}$ with inter-row spacing of $70 \mathrm{~cm}$. The terms of sowing were: 1st of May in 2014, 22nd of May in 2015 and 21st of May in 2016, respectively. Herbicide Harnes (Acetochlor, $900 \mathrm{~g} \mathrm{l}^{-1}$ of the active substance) was applied in the pre-sowing period in the $2.0 \mathrm{l} \mathrm{ha}^{-1}$ dose. Karate Zeon insecticide (Lambda-cyhalothrin, $50 \mathrm{~g} \mathrm{l}^{-1}$ of the active substance) was used at the 3-5 leaves crop stage in the $0.21 \mathrm{ha}^{-1}$ dose.
Master Power herbicide (Foramsulfuron, $31.5 \mathrm{~g} \mathrm{l}^{-1}$, Iodosulfuron, $1.0 \mathrm{~g} \mathrm{l}^{-1}$, Tienecarbazon-methyl, $10 \mathrm{~g} \mathrm{l}^{-1}$, Cyprosulfamide (antidote), $15 \mathrm{~g} \mathrm{l}^{-1}$ of the active substances) was applied at the 7-8 leaves crop stage in the $1.25 \mathrm{l} \mathrm{ha}^{-1}$ dose. Koragen insecticide (Chlorantraniliprole, $200 \mathrm{~g} \mathrm{l}^{-1}$ of the active substance) was used at the beginning of the panicle earing crop stage in the $0.1 \mathrm{l} \mathrm{ha}^{-1}$ dose. Soil humidity during the sweet corn vegetation period was kept up at $80 \%$ of the field capacity by drip irrigation. The total average content of the irrigation water applied was $1500 \mathrm{~m}^{3} \mathrm{ha}^{-1}$ during the crop vegetation period.

Data processing. The multi-factor analysis of variance (ANOVA) was conducted using the standard methodology (Rosner, 2006; Kim, 2014). Linear regression analysis was conducted by using the common calculation methods (Montgomery et al., 2012; Seber \& Lee, 2012; Draper \& Smith, 2014).

\section{Table 1}

Meteorological data for the period of sweet corn cultivation in the field experiments (from 2014 to 2016)

\begin{tabular}{|c|c|c|c|c|c|c|c|c|c|c|c|c|c|}
\hline \multirow[b]{2}{*}{ Month } & \multirow[b]{2}{*}{ Decade } & \multicolumn{4}{|c|}{ Air temperature, ${ }^{\circ} \mathrm{C}$} & \multicolumn{4}{|c|}{ Relative humidity, \% } & \multicolumn{4}{|c|}{ Rainfall, mm } \\
\hline & & 2014 & 2015 & 2016 & $\begin{array}{l}\text { long-term } \\
\text { mean }\end{array}$ & 2014 & 2015 & 2016 & $\begin{array}{l}\text { long-term } \\
\text { mean }\end{array}$ & 2014 & 2015 & 2016 & $\begin{array}{c}\text { long-term } \\
\text { mean }\end{array}$ \\
\hline \multirow{3}{*}{ May } & I & 13.7 & $13.9^{*}$ & $14.5^{*}$ & 14.1 & 75 & $77^{*}$ & $72^{*}$ & 63 & 33.0 & $13.7^{*}$ & $12.7^{*}$ & 15.0 \\
\hline & II & 17.8 & $17.4^{*}$ & $15.3^{*}$ & 16.6 & 75 & $62^{*}$ & $79^{*}$ & 62 & 5.2 & $2.5^{*}$ & $38.3^{*}$ & 14.0 \\
\hline & III & 22.2 & 19.6 & 18.5 & 17.4 & 61 & 69 & 77 & 66 & 0.0 & 70.7 & 20.7 & 13.0 \\
\hline \multirow{3}{*}{ June } & I & 22.4 & 21.3 & 17.8 & 19.2 & 64 & 61 & 70 & 68 & 13.3 & 7.1 & 16.2 & 13.0 \\
\hline & II & 20.0 & 21.3 & 21.9 & 19.5 & 58 & 67 & 75 & 65 & 28.6 & 3.4 & 12.8 & 18.0 \\
\hline & III & 20.0 & 20.0 & 26.5 & 21.2 & 64 & 73 & 62 & 67 & 22.5 & 27.8 & 14.0 & 14.0 \\
\hline \multirow{3}{*}{ July } & I & 23.5 & 22.8 & 22.4 & 21.3 & 53 & 74 & 61 & 62 & 0.0 & 84.9 & 21.6 & 22.0 \\
\hline & II & 25.5 & 21.0 & 25.8 & 22.3 & 56 & 66 & 59 & 61 & 9.4 & 19.7 & 0.0 & 14.0 \\
\hline & III & 26.1 & 26.0 & 25.0 & 22.1 & 49 & 67 & 54 & 61 & 10.0 & 0.0 & 24.7 & 13.0 \\
\hline August & I & $27.8^{*}$ & 26.0 & 26.0 & 22.4 & $45^{*}$ & 49 & 55 & 61 & $11.1^{*}$ & 0.0 & 0.6 & 7.0 \\
\hline
\end{tabular}

Notes: long-term means are given for the period of 1986-2005; the symbol * marks the decades when the crop was not sown yet or had been already harvested.

The artificial neural network (ANN) was designed by using the NeuroXL Predictor add-in within MS Excel 2010 software application (Patel \& Patel, 2011). Default NeuroXL Predictor settings were used for the network training and prediction, except the activation function type (zero-based log-sigmoid was used) and neurons quantity in the hidden layer (10 neurons were used). The sigmoid function is a mathematical function having a characteristic $S$ - sigmoid curve:

$$
S=\frac{1}{1+e^{-x}}
$$

We used the coefficient of determination (R2) values for the comparison of the linear regression and ANN prediction accuracy (Devore, 2011). The coefficient of determination was calculated by using the formula:

$$
R^{2}=1-\frac{V(y \mid x)}{V(y)}
$$

where is the dispersion of the dependent argument.

\section{Results}

Sweet corn yields. The experiments determined significant impact of the studied factors on the sweet corn yields. It was established that the maximum crop productivity was achieved by conducting the moldboard plowing at the depth of 20-22 cm, application of the mineral fertilizers at $\mathrm{N}_{120} \mathrm{P}_{120}$ rates, maintaining plant density at 65,000 plants ha ${ }^{-1}$ level. The highest yields of the ears without husks was $10.93 \mathrm{t} \mathrm{ha}^{-1}$ (Table 2).

Dataset construction. The dataset for modeling was created by using the yield data. The studied factors (moldboard plowing depths, fertilization application rates and plants densities) were used as inputs of the mathematical models, and sweet corn yield was used as an output. All the inputs were expressed in digital quantitative form to ensure adequate data processing (Table 3).

Linear regression prediction. The calculated values of the coefficients of regression showed that plowing depth increase led to a decrease in sweet corn yields by $97.2 \mathrm{~kg} \mathrm{ha}^{-1}$ for every cm; increase in fertilizer application rates by $1 \mathrm{~kg} \mathrm{ha}^{-1}$ of the active substance led to an increase in sweet corn yields by $43.6 \mathrm{~kg} \mathrm{ha}^{-1}$; increase in plant densities by 1,000 plants ha $^{-1}$ led to an increase in sweet corn yield by $26.5 \mathrm{~kg} \mathrm{ha}^{-}$ ${ }^{1}$ (Table 4).

\section{Table 2}

Average three-year (2014-2016 years) sweet corn yields (in ears without husks) depending on the moldboard plowing depths,

\begin{tabular}{|c|c|c|c|c|c|}
\hline \multirow{2}{*}{$\begin{array}{l}\text { Factor A } \\
\text { (Moldboard } \\
\text { plowing } \\
\text { depths, cm) }\end{array}$} & \multirow{2}{*}{$\begin{array}{c}\text { Factor C } \\
\text { (Plant } \\
\text { densities, } \\
\text { plants ha' }^{-1} \text { ) }\end{array}$} & \multicolumn{3}{|c|}{$\begin{array}{l}\text { Factor B (fertilizer application rates, } \\
\qquad \mathrm{kg} \mathrm{ha}^{-1} \text { ) }\end{array}$} & \multirow{2}{*}{$\begin{array}{c}\text { Mean } \\
\text { - values by } \\
\text { the Factor A }\end{array}$} \\
\hline & & $\begin{array}{c}\text { No } \\
\text { fertilizers }\end{array}$ & $\mathrm{N}_{60} \mathrm{P}_{60}$ & $\mathrm{~N}_{120} \mathrm{P}_{120}$ & \\
\hline \multirow{4}{*}{$20-22$} & 35000 & $2.67 \pm 0.30$ & $5.56 \pm 0.57$ & $7.53 \pm 0.88$ & \multirow{4}{*}{6.22} \\
\hline & 50000 & $2.85 \pm 0.28$ & $6.31 \pm 1.03$ & 8.81 & \\
\hline & 65000 & $3.01 \pm 0.34$ & $7.67 \pm 0$ & 10.93 & \\
\hline & 80000 & $2.96 \pm 0.35$ & $6.80 \pm 1.15$ & & \\
\hline \multirow{4}{*}{$28-30$} & 35000 & $3.00 \pm 0.33$ & $4.89 \pm 0$ & 6.23 & \multirow{4}{*}{5.45} \\
\hline & 50000 & $3.34 \pm 0.38$ & $5.55 \pm 0.54$ & $7.36 \pm$ & \\
\hline & & $3.57 \pm 0.43$ & $6.25 \pm 0$ & 8.59 & \\
\hline & 80000 & $3.37 \pm 0.39$ & $5.64 \pm 0.60$ & $7.56 \pm 0.92$ & \\
\hline \multicolumn{2}{|c|}{ Mean values by the Factor $B$} & 3.10 & 6.08 & 8.32 & - \\
\hline \multicolumn{2}{|c|}{ Mean values by the Factor $C$} & 4.98 & 5.70 & 6.67 & 5.99 \\
\hline
\end{tabular}
fertilizer application rates and plant densities, expressed in $\mathrm{tha}^{-1}$

Notes: the multi-factor ANOVA results: LSD (the least significant difference) at $\mathrm{P}<0.05$ : Factor $\mathrm{A}-0.10$; Factor $\mathrm{B}-0.07$; Factor $\mathrm{C}-0.12$; factors interaction $\mathrm{ABC}-0.32 \mathrm{t} \mathrm{ha}^{-1}$; all the treatments are significantly different at $\mathrm{P}<0.05$; the standard deviation values (SD) are given in brakes.

According to the calculated values of the coefficients of regression the linear model looked like:

$$
\mathrm{Y}=4.0270-0.0972 \mathrm{X}_{1}+0.0436 \mathrm{X}_{2}+0.0265 \mathrm{X}_{3} \text {, }
$$

where $\mathrm{Y}$ is the sweet corn yields; $\mathrm{X}_{1}$ is the moldboard plowing depth expressed in cm; $X_{2}$ is the fertilizer application rates expressed in $\mathrm{kg} \mathrm{ha}^{-1}$ of the active substance; $X_{3}$ is the plant densities expressed in plants ha ${ }^{-1}$.

Artificial neural network prediction. Prediction by the means of ANN was conducted by the NeuroXL Predictor add-in within MS Excel software application. The application does not provide sufficient details about data processing, modeling and prediction. Thereby assessment of the model and its parameters is impossible. NeuroXL Predictor is an easy and smart tool with no excessive actions or settings needs, which provides ready predictions and graphics for users. 
Table 3

Dataset for comparison of the artificial neural network and linear regression accuracy in the sweet corn yields prediction depending on the cultivation technology parameters

\begin{tabular}{|c|c|c|c|}
\hline \multicolumn{3}{|c|}{ Inputs } & \multirow{2}{*}{$\begin{array}{c}\text { Output } \\
\begin{array}{c}\text { Sweet corn } \\
\text { yields, } \text { tha }^{-1}\end{array}\end{array}$} \\
\hline $\begin{array}{l}\text { Factor A (moldboard } \\
\text { plowing depths, cm) }\end{array}$ & $\begin{array}{c}\text { Factor B (fertilizer } \\
\text { application rates, } \mathrm{kg} \mathrm{ha}^{-1} \text { ) }\end{array}$ & $\begin{array}{c}\text { Factor C (plant } \\
\text { densities, plants ha }{ }^{-1} \text { ) }\end{array}$ & \\
\hline 20 & 0 & 35000 & 2.67 \\
\hline 20 & 0 & 50000 & 2.85 \\
\hline 20 & 0 & 65000 & 3.01 \\
\hline 20 & 0 & 80000 & 2.96 \\
\hline 20 & 60 & 35000 & 5.56 \\
\hline 20 & 60 & 50000 & 6.31 \\
\hline 20 & 60 & 65000 & 7.67 \\
\hline 20 & 60 & 80000 & 6.80 \\
\hline 20 & 120 & 35000 & 7.53 \\
\hline 20 & 120 & 50000 & 8.81 \\
\hline 20 & 120 & 65000 & 10.93 \\
\hline 20 & 120 & 80000 & 9.58 \\
\hline 28 & 0 & 35000 & 3.00 \\
\hline 28 & 0 & 50000 & 3.34 \\
\hline 28 & 0 & 65000 & 3.57 \\
\hline 28 & 0 & 80000 & 3.37 \\
\hline 28 & 60 & 35000 & 4.89 \\
\hline 28 & 60 & 50000 & 5.55 \\
\hline 28 & 60 & 65000 & 6.25 \\
\hline 28 & 60 & 80000 & 5.64 \\
\hline 28 & 120 & 35000 & 6.23 \\
\hline 28 & 120 & 50000 & 7.56 \\
\hline 28 & 120 & 65000 & 8.59 \\
\hline 28 & 120 & 80000 & 7.56 \\
\hline
\end{tabular}

Table 4

Regression analysis results for the sweet corn yields

(in ears without husks) depending on the moldboard plowing depths, fertilizer application rates and plant densities

\begin{tabular}{lccrrr}
\hline Treatments & $\begin{array}{c}\text { Coefficients } \\
\text { of correlation }\end{array}$ & $\begin{array}{c}\text { Coefficients of } \\
\text { determination }\end{array}$ & $\begin{array}{c}\text { Coefficient } \\
\text { s of } \\
\text { regression }\end{array}$ & $\begin{array}{c}\text { Student } \\
\text { criterion }\end{array}$ & $\begin{array}{c}\text { Student } \\
\text { criterion } \\
\text { at } \mathrm{P}<0.05\end{array}$ \\
\hline $\mathrm{X}_{1} \mathrm{X}_{2} \mathrm{X}_{3}$ & 0.947 & 0.897 & 4.0270 & 3.388 & \\
$\mathrm{X}_{1}$ & -0.166 & 0.028 & -0.0972 & -2.319 & 2.069 \\
$\mathrm{X}_{2}$ & 0.913 & 0.833 & 0.0436 & 12.729 & \\
$\mathrm{X}_{3}$ & 0.190 & 0.036 & 0.0265 & 2.655 & \\
\hline
\end{tabular}

Notes: $\mathrm{X}_{1}$ is the moldboard plowing depth expressed in $\mathrm{cm} ; \mathrm{X}_{2}$ is the fertilizer application rates expressed in $\mathrm{kg} \mathrm{ha}^{-1}$ of the active substance; $\mathrm{X}_{3}$ is the plant densities expressed in plants $\mathrm{ha}^{-1}$.
The results of the predictions in comparison to the true yield values are given in the Table 5. It was determined that the coefficient of determination $\left(\mathrm{R}^{2}\right)$ value of the linear regression model was 0.897 , compared to 0.978 of the artificial neural network one. This proves the higher accuracy of the artificial neural network prediction. Graphical expression of the prediction models is given in Figure 1.

\section{Table 5}

True and predicted by the artificial neural network and linear regression values of the sweet corn yields (in ears without husks) depending on the cultivation technology parameters with residuals, expressed in $\mathrm{tha}^{-1}$

\begin{tabular}{ccccc}
\hline $\begin{array}{c}\text { True yield } \\
\text { values }\end{array}$ & $\begin{array}{c}\text { ANN } \\
\text { predicted } \\
\text { yields }\end{array}$ & $\begin{array}{c}\text { Linear } \\
\text { regression } \\
\text { predicted yields }\end{array}$ & $\begin{array}{c}\text { Residuals for the } \\
\text { ANN prediction }\end{array}$ & $\begin{array}{c}\text { Residuals for the } \\
\text { inear regression } \\
\text { prediction }\end{array}$ \\
\hline 2.67 & 3.19 & 3.01 & -0.52 & -0.34 \\
2.85 & 2.70 & 3.41 & 0.15 & -0.56 \\
3.01 & 2.88 & 3.81 & 0.13 & -0.80 \\
2.96 & 3.44 & 4.20 & -0.48 & -1.24 \\
5.56 & 5.57 & 5.63 & -0.01 & -0.07 \\
6.31 & 6.20 & 6.02 & 0.11 & 0.29 \\
7.67 & 7.27 & 6.42 & 0.40 & 1.25 \\
6.80 & 6.71 & 6.82 & 0.09 & -0.02 \\
7.53 & 7.57 & 8.24 & -0.04 & -0.71 \\
8.81 & 9.16 & 8.64 & -0.35 & 0.17 \\
10.93 & 10.17 & 9.04 & 0.76 & 1.89 \\
9.58 & 10.19 & 9.44 & -0.61 & 0.14 \\
3.00 & 3.03 & 2.23 & -0.03 & 0.77 \\
3.34 & 3.44 & 2.63 & -0.10 & 0.71 \\
3.57 & 3.51 & 3.03 & 0.06 & 0.54 \\
3.37 & 2.96 & 3.43 & 0.41 & -0.06 \\
4.89 & 4.34 & 4.85 & 0.55 & 0.04 \\
5.55 & 5.95 & 5.25 & -0.40 & 0.30 \\
6.25 & 6.48 & 5.64 & -0.23 & 0.61 \\
5.64 & 5.76 & 6.04 & -0.12 & -0.40 \\
6.23 & 6.28 & 7.46 & -0.05 & -1.23 \\
7.56 & 7.74 & 7.86 & -0.18 & -0.30 \\
8.59 & 7.98 & 8.26 & 0.61 & 0.33 \\
7.56 & 7.78 & 8.66 & -0.22 & -1.10 \\
\hline & & & &
\end{tabular}

\section{Discussion}

Regression models are widely used in agriculture for different purposes: crop yield prediction depending on cultivation technology, soil properties and water use efficiency, etc. (Ahmad et al., 2015; Possinger \& Amador, 2016; Reid, 2017; Williams, 2017). It should be mentioned that linear regression provides a sufficiently accurate prediction, especially, when weighted least squares are used (Almeida et al., 2002; Weisberg, 2005).

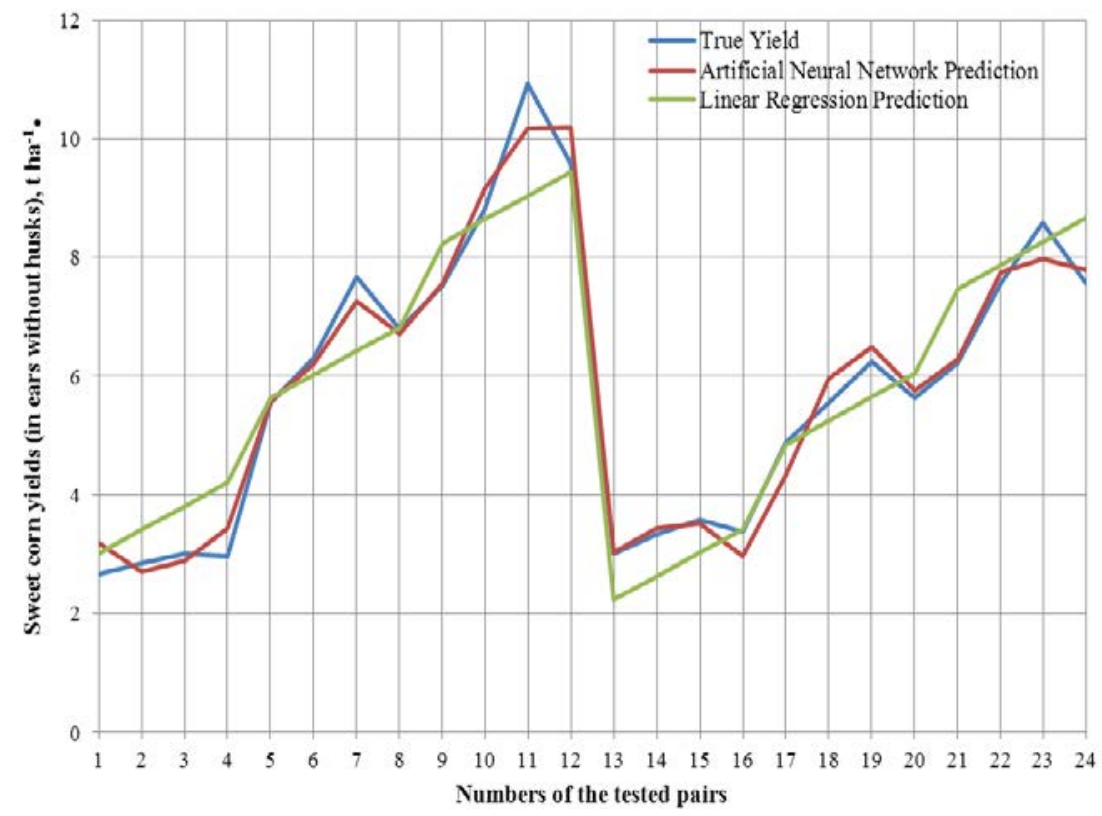

Fig. 1. Sweet corn yields (in ears without husks) prediction accuracy by using the linear regression and artificial neural network methods 
Our study has substantiated the above-mentioned statement. Its main advantages are simplicity and easy access to the model parameters. The calculated values of the regression coefficients may be used by scientists in assessing the effect of the studied factors on the investigated object or phenomenon. ANNs are currently in great demand in different branches of agricultural and agroecological sciences. The method is used in crop yield prediction, climate change, soil properties, etc. (Dahikar \& Rode, 2014; Dai et al., 2014; Deo \& Sahin, 2015; Tabari et al., 2015; Vani et al., 2015; Le et al., 2016). The main advantages of ANNs are their high accuracy, ability to handle large and complex systems, non-linear algorithms, ability to process incomplete datasets and learning (Kalogirou, 2000; Wang et al., 2015). It was proved that the multiple perceptron artificial neural network is better than other methods of modeling and prediction (Choubin et al., 2016). On the other hand, their "black box" nature and difficulty for ordinary users are weak points (Tu, 1996). Our study has proved some recently stated conclusions about the greater possibilities of ANN use in different scientific investigations, especially, nature-related and agricultural (Altay \& Satman, 2005; Yilmaz \& Kaynar, 2011; Lee et al., 2017). But the question remains open because some scientific studies have established no significant advantages in ANN use comparative to the standard statistical data processing methods, viz. multiple linear and non-linear regressions (Sargent, 2001; Rezaeianzadeh et al., 2014). It has been mathematically proved that regression models are not worse than artificial neural network models. It should be mentioned that a few studies have stated that multiple-linear regression performed insignificantly better than ANN in prediction of different phenomena. Some researchers propose using a hybrid ANN and fuzzy regression model for time series forecasting to obtain the most accurate prediction results. Some studies state that regression and artificial neural network models should be used for different purposes, because each method is good for a concrete purpose (Khashei et al., 2008; Ghorbani et al., 2015; Khademi et al., 2016). It has also been stated that no single comparison of ANNs with regression models could provide the true end results (Eftekhar et al., 2005).

\section{Conclusions}

Artificial neural networks are an highly efficient and accurate method of modeling and prediction of natural processes. The method is a great deal better in prediction than standard linear regression because of its higher accuracy related to its non-linear nature. However, linear regression will not lose its relevance and popularity among scientists in the nearest future, because of its ease of use and sufficient level of accuracy in prediction.

\section{References}

Ahmad, A. A., Radovich, T. J., \& Hue, N. V. (2015). Effect of intercropping three legume species on growth and yield of sweet com (Zea mays) in Hawaii. Journal of Crop Improvement, 29(3), 370-378.

Altay, E., \& Satman, M. H. (2005). Stock market forecasting: artificial neural network, and linear regression comparison in an emerging market. Journal of Financial Management and Analysis, 18(2), 18.

Almeida, A. M. D., Castel-Branco, M. M., \& Falcao, A. C. (2002). Linear regression for calibration lines revisited: Weighting schemes for bioanalytical methods. Journal of Chromatography B, 774(2), 215-222.

Alvarez, R. (2009). Predicting average regional yield and production of wheat in the Argentine Pampas by an artificial neural network approach. European Journal of Agronomy, 30(2), 70-77.

Atici, U. (2011). Prediction of the strength of mineral admixture concrete using multivariable regression analysis and an artificial neural network. Expert Systems with Applications, 38(8), 9609-9618.

Choubin, B., Khalighi-Sigaroodi, S., Malekian, A., \& Kiși, Ö. (2016). Multiple linear regression, multi-layer perceptron network and adaptive neuro-fuzzy inference system for forecasting precipitation based on large-scale climate signals. Hydrological Sciences Journal, 61(6), 1001-1009.

Comrie, A. C. (1997). Comparing neural networks and regression models for ozone forecasting. Journal of the Air and Waste Management Association, 47(6), 653-663.

Cross, S. S., Harrison, R. F., \& Kennedy, R. L. (1995). Introduction to neural networks. The Lancet, 346(8982), 1075-1079.
Dahikar, S. S., \& Rode, S. V. (2014). Agricultural crop yield prediction using artificial neural network approach. International Journal of Innovative Research in Electrical, Electronics, Instrumentation and Control Engineering, 2(1), 683-686.

Dai, F., Zhou, Q., Lv, Z., Wang, X., \& Liu, G. (2014). Spatial prediction of soil organic matter content integrating artificial neural network and ordinary kriging in Tibetan Plateau. Ecological Indicators, 45, 184-194.

Deo, R. C., \& Şahin, M. (2015). Application of the artificial neural network model for prediction of monthly standardized precipitation and evapotranspiration index using hydrometeorological parameters and climate indices in eastern Australia. Atmospheric Research, 161, 65-81.

Devore, J. L. (2011). Probability and statistics for engineering and the sciences. Cengage learning, Boston.

Draper, N. R., \& Smith, H. (2014). Applied regression analysis. John Wiley \& Sons, New York.

Eftekhar, B., Mohammad, K., Ardebili, H. E., Ghodsi, M., \& Ketabchi, E. (2005). Comparison of artificial neural network and logistic regression models for prediction of mortality in head trauma based on initial clinical data. BMC Medical Informatics and Decision Making, 5(1), 3.

Ghorbani, H., Kashi, H., Hafezi Moghadas, N., \& Emamgholizadeh, S. (2015). Estimation of soil cation exchange capacity using multiple regression, artificial neural networks, and adaptive neuro-fuzzy inference system models in Golestan Province, Iran. Communications in Soil Science and Plant Analysis, 46(6), 763-780.

Ji, B., Sun, Y., Yang, S., \& Wan, J. (2007). Artificial neural networks for rice yield prediction in mountainous regions. The Journal of Agricultural Science, 145(3), 249-261.

Kalogirou, S. A. (2000). Applications of artificial neural-networks for energy systems. Applied Energy, 67(1), 17-35.

Kaul, M., Hill, R. L., \& Walthall, C. (2005). Artificial neural networks for corn and soybean yield prediction. Agricultural Systems, 85(1), 1-18.

Khademi, F., Jamal, S. M., Deshpande, N., \& Londhe, S. (2016). Predicting strength of recycled aggregate concrete using artificial neural network, adaptive neuro-fuzzy inference system and multiple linear regression. Intemational Journal of Sustainable Built Environment, 5(2), 355-369.

Khashei, M., Hejazi, S. R., Bijari, M. (2008). A new hybrid artificial neural networks and fuzzy regression model for time series forecasting. Fuzzy Sets and Systems, 159(7), 769-786.

Kim, H.-Y. (2014). Analysis of variance (ANOVA) comparing means of more than two groups. Restorative Dentistry and Endodontics, 39(1), 74-77.

Le, M. H., Perez, G. C., Solomatine, D., \& Nguyen, L. B. (2016). Meteorological drought forecasting based on climate signals using artificial neural network A case study in Khanhhoa Province Vietnam. Procedia Engineering, 154, 1169-1175.

Lee, K.-Y., Kim, K.-H., Kang, J.-J., \& Choi, S.-J. (2017). Comparison and analysis of linear regression and artificial neural network. International Journal of Applied Engineering Research, 12(20), 9820-9825.

Lek, S., \& Guégan, J. F. (1999). Artificial neural networks as a tool in ecological modelling, an introduction. Ecological Modelling, 120(2), 65-73.

Lek, S., Delacoste, M., Baran, P., Dimopoulos, I., Lauga, J., \& Aulagnier, S. (1996). Application of neural networks to modelling nonlinear relationships in ecology. Ecological Modelling, 90(1), 39-52.

Merdun, H., Çınar, Ö., Meral, R., \& Apan, M. (2006). Comparison of artificial neural network and regression pedotransfer functions for prediction of soil water retention and saturated hydraulic conductivity. Soil and Tillage Research, 90(1-2), 108-116.

Montgomery, D. C., Peck, E. A., \& Vining, G. G. (2012). Introduction to linear regression analysis (Vol. 821). John Wiley \& Sons, New York City.

Panda, S. S., Ames, D. P., \& Panigrahi, S. (2010). Application of vegetation indices for agricultural crop yield prediction using neural network techniques. Remote Sensing, 2(3), 673-696.

Patel, P. D., \& Patel, S. P. (2011). Prediction of weld strength of metal active gas (MAG) welding using artificial neural network. International Journal of Engineering Research and Applications, 1(1), 36-44.

Possinger, A. R., \& Amador, J. A. (2016). Preliminary evaluation of seaweed application effects on soil quality and yield of sweet corn (Zea mays L.). Communications in Soil Science and Plant Analysis, 47(1), 121-135.

Refenes, A. N., Zapranis, A., \& Francis, G. (1994). Stock performance modeling using neural networks: A comparative study with regression models. Neural Networks, 7(2), 375-388.

Reid, J. B. (2017). A preliminary model of sweet corn growth and yield. New Zealand Journal of Crop and Horticultural Science, 45(2), 130-149.

Rezaeianzadeh, M., Tabari, H., Yazdi, A. A., Isik, S., \& Kalin, L. (2014). Flood flow forecasting using ANN, ANFIS and regression models. Neural Computing and Applications, 25(1), 25-37.

Rosner, B. (2006). Fundamentals of biostatistics. Duxbury Press, Belmont CA.

Sargent, D. J. (2001). Comparison of artificial neural networks with other statistical approaches. Cancer, 91(S8), 1636-1642. 
Seber, G. A., \& Lee, A. J. (2012). Linear regression analysis (Vol. 936). John Wiley \& Sons, New York.

Tabari, H., Hosseinzadeh Talaee, P., \& Willems, P. (2015). Short-term forecasting of soil temperature using artificial neural network. Meteorological Applications, 22(3), 576-585.

Tu, J. V. (1996). Advantages and disadvantages of using artificial neural networks versus logistic regression for predicting medical outcomes. Journal of Clinical Epidemiology, 49(11), 1225-1231.

Uno, Y., Prasher, S. O., Lacroix, R., Goel, P. K., Karimi, Y., Viau, A., \& Patel, R. M. (2005). Artificial neural networks to predict corn yield from Compact Airborne Spectrographic Imager data. Computers and Electronics in Agriculture, 47(2), 149-161.

Vani, S., Sukumaran, R. K., \& Savithri, S. (2015). Prediction of sugar yields during hydrolysis of lignocellulosic biomass using artificial neural network modeling. Bioresource Technology, 188, 128-135.
Wang, W. C., Chau, K. W., Qiu, L., \& Chen, Y. B. (2015). Improving forecasting accuracy of medium and long-term runoff using artificial neural network based on EEMD decomposition. Environmental Research, 139, 46-54.

Weisberg, S. (2005). Applied linear regression (Vol. 528). John Wiley \& Sons, New York.

Williams, M. M. (2017). Genotype adoption in processing sweet corn relates to stability in case production. HortScience, 52(12), 1748-1754.

Yilmaz, I., \& Kaynar, O. (2011). Multiple regression, ANN (RBF, MLP) and ANFIS models for prediction of swell potential of clayey soils. Expert Systems with Applications, 38(5), 5958-5966.

Zhang, G., Patuwo, B. E., \& Hu, M. Y. (1998). Forecasting with artificial neural networks: The state of the art. International Joumal of Forecasting, 14(1), 35-62. 